\title{
INVESTIGATING TILING DECORATIONS OFSAFAVID PERIOD, A CASE STUDY SHEIKH LOTFOLLAH MOSQUE OF ISFAHAN
}

\author{
Hooman Sobouti \\ Department of Architecture, Zanjan Branch, Islamic Azad University, Zanjan, Iran \\ Young Researchers and Elites Club, Zanjan Branch, Islamic Azad University, Zanjan, Iran \\ hoomansobouti@znu.ac.ir \\ Hamed Ebadei \\ Department of Architecture, Zanjan Branch, Islamic Azad University, Zanjan, Iran. \\ Hamedebadi1988@gmail.com
}

\begin{abstract}
Safavids were the true heirs of the magnificent art of Timurid period. In fact tiling art reaches the peak of its prosperity in Safavid era. An important reason for the flourishing of tiling art in this period is Shah Abbas's interest in tile work and embellishment of mosques and holy shrines of Imams with tiling decorations. One of the most elegant monuments of Isfahan which catches the eyes of every viewer is Sheikh Lotfollah mosque. The significance of this building is due to its architecture which is imbued with talent and artistic excellence, thus elevating its worth. In the present article conducted by descriptive analytical method, the zenith of tile work, application of arabesque lines along with the unmatched masterpiece of the period; that is Sheikh Lotfollah mosque will be discussed.
\end{abstract}

Keywords: The Safavid, tiling art, Sheikh Lotfollah mosque

\section{INTRODUCTION}

One of the most brilliant periods of Iranian art after Islam is the Safavid period. During this time all religious buildings were embellished with tiling decorations (Shaterian, 2011). Shah Abbas's interest in covering holy shrines of Imams as well as mosques with tiling decorations could be the reason of the consummation of tiling art in this period. The major assistant of Shah Abbas in making these ambitious architectural designs scientific,was a prominent man called Sheikh Baha al-Din Mohammad Ameli (Sheikh Bahayi). He was known as a great divine scholar, philosopher, commentator of the Quran, jurist, astronomer, poet and engineer of the Safavid society and the great Shah Abbas period (Sivari, 1995). Tiling of buildings in the Safavid era was based on practices in centuries prior to the Seljuks, the only difference was that the ancient mosaic tiles were gradually replaced with patterned tiles. Fortunately almost all of these buildings are well-preserved. (Talboot, 1996).

Designs of tiles along with their colors have granted special charm to the buildings of this period. Not only walls, but domes, minarets, entrances, arcades, and patios are decorated with tiles and mosaic. Building large entrances with transparent tiles and plaster muqarnas work in Safavid era had great improvement (Shaterian, 2011). Moreover, since mosques are the most important Islamic buildings, it can be said that Islamic art originally emerged in mosques, and these places can be regarded as the most important manifestations of Islamic architecture and art at the same time (Alrefayi, 1998).

\section{STATEMENT OF THE PROBLEM}


Tiling of Iranian mosques is as important an issue as the architectural construction itself, just as the skin of a living organism is irreplaceable with the skeleton, muscle or flesh of its body. In fact this cover is not a clothing which can be removed without making any significant changes in terms of its meaning. Therefore engaging in spatial analysis is called for and essential, through which one can figure out the reasons for locations of decorations, the meticulous rules governing its analysis as well as the key to understanding the reasons for the fundamental importance of tiling (Yavari, 2011). The most prominent decorative element in Islamic architecture is tile and since the Ilkhanid period, almost no building can be found which did not utilize tile decorations.

\section{SAFAVID PERIOD ARCHITECTURE}

In Safavid period, Shiism was declared as the official religion of Iran. During this period, Shiismwas the focus of attention in Islamic architecture and this interest is frequently observed in buildings belonging to this period. Kings, artists and architects of this era insisted on creating a kind of unity and solidarity among people, so as to represent divine unity. This resulted in the creation of a style in Islamic architecture known as Isfahani style which is one of the four Islamic-Iranian architectures. The style is based on further simplicity in design and geometry of buildings, so as to represent the simplicity of Islam.

Another principle of this style is the equality of proportions in buildings, representing the equality of men before the divine justice. Since the emergence of Safavid dynasty brought about intense national pride, engaging in wars primarily hampered the construction of any large scale architecture. With the emergence of Shah Abbas the First, however, the golden age of Safavid architecture started. Although the architecture in this period was not the most brilliant architectural era in Iran, it was the period of prominence and the ultimate demonstration of Iranian-Islamic architecture. Isfahan which was chosen as the capital city by Shah Abbas, enjoyed numerous mosques, palaces, bridges, streets and gardens. Color and decoration played critical rolesin Safavid architecture, and the buildings remaining from this period are gorgeous and unique in terms of appearance.

In fact Safavid period architecture was in favor of illuminating and decorating some parts of buildings, rather than making direct innovations. Traditional forms which were used in this period in large scale and without much endeavor, reached the summit of their perfection, such that the architectural style in Safavid period moved towards further simplicity. The geometry of the buildings were simple and instead of using winding lines frequently applied in past, shapes and broken lines were more common. Moreover, scaling and equal proportions wereutilized in buildings. However, various decorative techniques such as brick work, tiling, inscription, molding, mirror work, wood decorations and even several architectural elements including false crotches, muqarnas and three cornered shapes were used by architects and artists of this period in their fullest extent.

\section{TILING IN SAFAVID PERIOD}

One of the elegant arts in Iranian architecture is tiling art which in fact has been used as an alternative to painting on wall. Many believe that primarily Iran used tiles for the purpose of decorating as well as strengthening buildings. Shortly before Shah Abbas, tiling was not advanced, but since his time a movement was created in this art which can be witnessed in national and international museums. A significant reason for this was the particular interest of Shah Abbas in covering holy shrines of Imams and mosques with beautiful tiles and also his attention to the paining. In this period, the colored surface of tiles was mostly pale, with little use of green, black and red colors. Generally tiles were blue. In the reign of Shah Abbas, all the religious buildings uncovered with tiles were adorned with beautiful tiles by the artists. During this period, Sheikh Lotfollah mosque, the entrance of Qheisarieh (Bazar) and the shrines of Imams and their descendants were covered with mosaic tiles. The interior surface of the mosque was decorated with painted tiles as well. Designs of human figures, flowers and harmonious lines drawn by Reza Abbasi, the most conspicuous artist of the time, has been a role model for painting on walls and tiles. It is worth mentioning that in 
The Turkish Online Journal of Design, Art and Communication - TOJDAC July 2016 Special Edition

that period, complete set of pictures were made by square-shaped tiles, and arabesque and battle filed designs were applied frequently. At the end of this period, outstanding small rectangles with subtle glaze were commonly used for designing various pictures. It must be noted that after Shah Abbas period, colors were used differently, such that during Shah Soleiman period, red, yellow and orange colors were applied more and foliar motifs were replaced with geometric shapes.

\section{SHEIKH LOTFOLLAH MOSQUE}

The most elegant and magnificent building of the Safavid period is Sheikh Lotfollah mosque, located on the east side of NaghsheJahan square, in front of Alighapoo mansion. The building was finished in the reign of Shah Abbas the Great, in 1618. This mosque is named after its prayer Imam (Sheikh Lotfollah) who due to religious reasons, moved from Lebanon to Iran in the reign of Shah Abbas and settled in Mashhad and later in Isfahan. In this mosque and its adjacent one, Sheikh Lotfollah used to say prayer and teach religious sciences (Kiani, 2004). This mosque possesses an eye catching design with relatively small sizes. This is not a mosque with one courtyard and four patios, rather a mosque without a minaret, but only a chamber specific to saying prayer. This chamber is covered with an exquisite dome whose curved wall has sixteen windows. The lower part of this chamber is square, including an enclosed circular area dominated by simplicity, order and accuracy, as well as the integrity which has created a pure spotless atmosphere.

Here one can behold the four polished backgrounds of ceiling, extended up to the end. In the four parts of this square space, this background is in total compatibility with the four same-sized great vaults which surround the background. Thus the flat areas of the vault highlight the angled backgrounds and stand out the regular octagonal arches. Small surfaces which change the pendants of the southern vault to smaller divisions, create a polygonal with sixteen sides. Each of these small triangular surfaces are related and adapted to a window, and thus the mosque is constructed in accordance with absolute geometric order. Furthermore, all the constituent elements are orderedwith perfect forming features (art and architecture of mosques, 2005).

Among the remarkable features of this mosque is thecareful rotation of the interior area in relation with the entrance, which posits the altar right in front of the mosque's qibla. The urge to locate the vault towards qibla has obliged the architect to build a corridor with a subtle twist from the outside of the building through which the entrants are placed towards the qibla as they enter the vault (MousaviBojnoordi, 2005). "The corridor is covered with elegant tiles up to the ceiling, making the beholder feel as if he has stepped into a sea of tiles, soothing his soul, a corridor covered with arabesque twisted and abstract designs which culminate man's desire to worship and praise God. The design of this corridor, in addition to resolving the problem of locating the qibla, takes the worshiper away from all the hustles outside the mosque and the dim light of the corridor engages man in the magnificence, elegance and spiritual mood as he steps into the vault (Dadkhah, 2012).

The interior walls of the mosque's vault start with octagonal shapes, each of which are surrounded by turquois rope-like tiles which enclose the beautiful lines of AlirezaAbbasi like a frame with eight sides. These lines are written with dazzling white tiles amid dark blue tiles. The angles made by these eight sides form the basis of a large curvature. Nevertheless the gradual curvature of the dome hides the beginning point of the curve, as well as dome's great circle. Dome curvature is connected to the octagonal by kite-shaped angled walls. The next part of the wall tends towards great curve tradition, but the whole curve is so natural that is barely discerned.

The interior tiling of the dome is roughly the same size, embellishing the dome. All parts of this chamber are designed and decorated with utmost order, sequence and symmetry, since "Islamic art, in a sense, is an abstract and mystical art whose essence is manifested in symmetry. All its abstract order is a reflection of the mystic content which is built on 
The Turkish Online Journal of Design, Art and Communication - TOJDAC July 2016 Special Edition

Islamic ideology, and free from whimsical emotional responses (Hatam, 1997). The side walls are adorned with adjoining blue flowers and bushes in a cream background. The upper angles of the side walls are covered with flowers and bushes designed differently from the other parts, bestowing a special variety and beauty to the decorations of this complex. "The first thing one will notice in Islamic art features is that this art is realized in abstract forms, plants or geometric shapes called designs (Albasini, 2008).

Mosaic and seven-color tiles in this mosque are exquisitely elegant. "Basically starting the walls of the courtyard with seven-color tiles, then changing it to mosaic tiles create a pleasant variety per se (Honarfar, 2004). Decorations of the interior area of the dome are composed of repeated large golden stars covered with twisted ivy, surrounding the entire interior space of the dome. In addition to elegance, these designs have created an awesome rhythmic motif and fashioned a magnificent dynamic movement out of solid material. "Indeed the viewer primarily familiar with the azure walls of the building, involuntarily thinks that the arches of the indigo dome of sky are expanded on this high porch, as he lifts up his head to behold the majestic arches and transparent stars (Pope, 1963).

In the interior upper part of the dome, verses of Jumu'ah and Nasr surahs are written in Sols line. In the area of the chamber, the noble surahs of Qadr, Humazah, Kafirun, Ash-Sharh, Al-Fil, At-Tin and Al-Fatihah are written in Banayi lines with black tiles on a white background. In the four corners of the chamber, poems in Arabic including the names of the Fourteen Innocents (Imams) are written, the poet of which is apparently Sheikh Bahayi (Honarfar, 1971). Not even the slightest weakness is observed in this building. The sizes are quite appropriate, the design is truly effective and in short it is a compromise between a world of excitement and a majestic silence which represent the rich aesthetic taste whose origin is nothing but religious faith and divine inspiration. The creation of such artistic works is impossible without the faith in God and love of religion. The architect, painter and tile worker all endeavor to create a masterpiece, an evidence and proof of God (Pope, 2009) (picture 1).

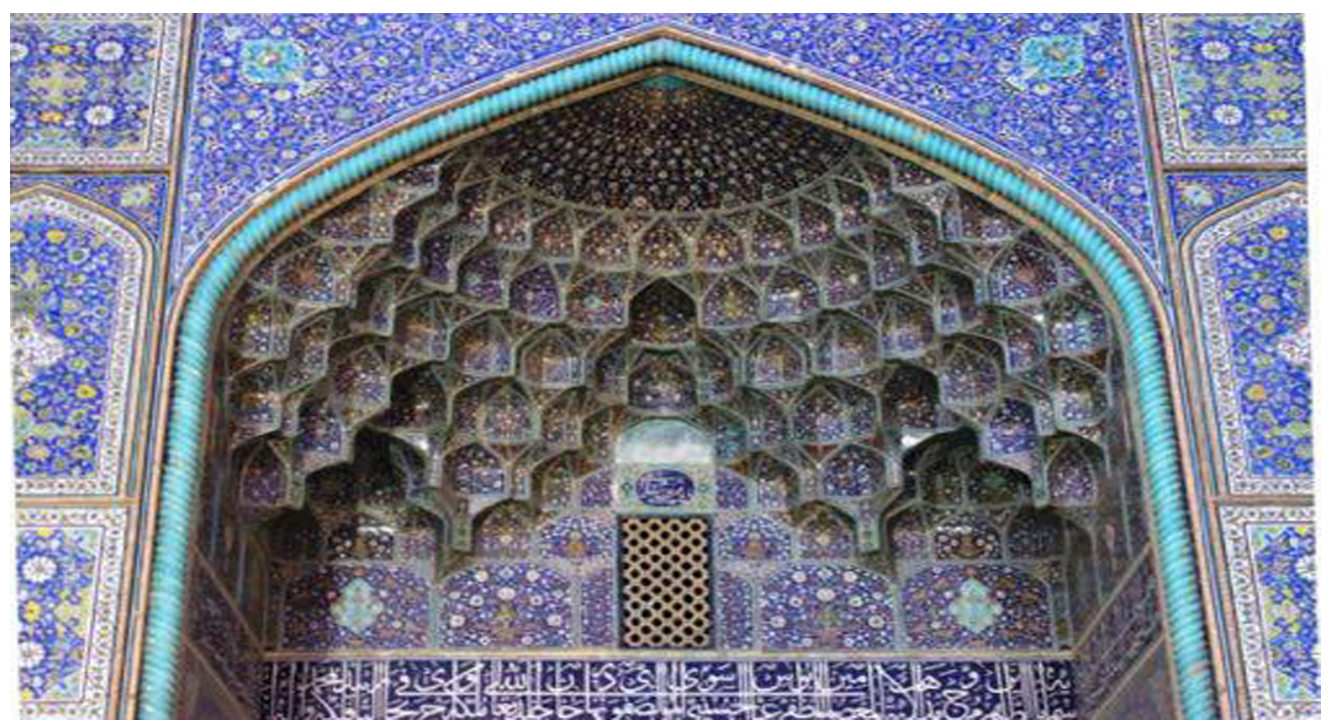

Picture- 1 source: the author

\section{TILES USED IN SHEIKH LOTFOLLAH MOSQUE MOSAIC TILE}

Mosaic work includes putting together the pieces cut from tile which are carved from different designs and colors in large pieces and are attached to the background. Using mosaic tiles began in Ilkhanid period and had its utmost decorative application in Timurid and Safavid period (Makkinejad, 2009). Using seven-color tiles in decorative works of Safavid period did not phase out mosaic tiles, and mosaic work still adorned the architecture of Safavid period. Among the outstanding examples of mosaic tiles, the ulterior 
The Turkish Online Journal of Design, Art and Communication - TOJDAC July 2016 Special Edition

cover of Sheikh Lotfollah mosque, as well as Quranic inscriptions in Sols writing can be enumerated (picture 2).

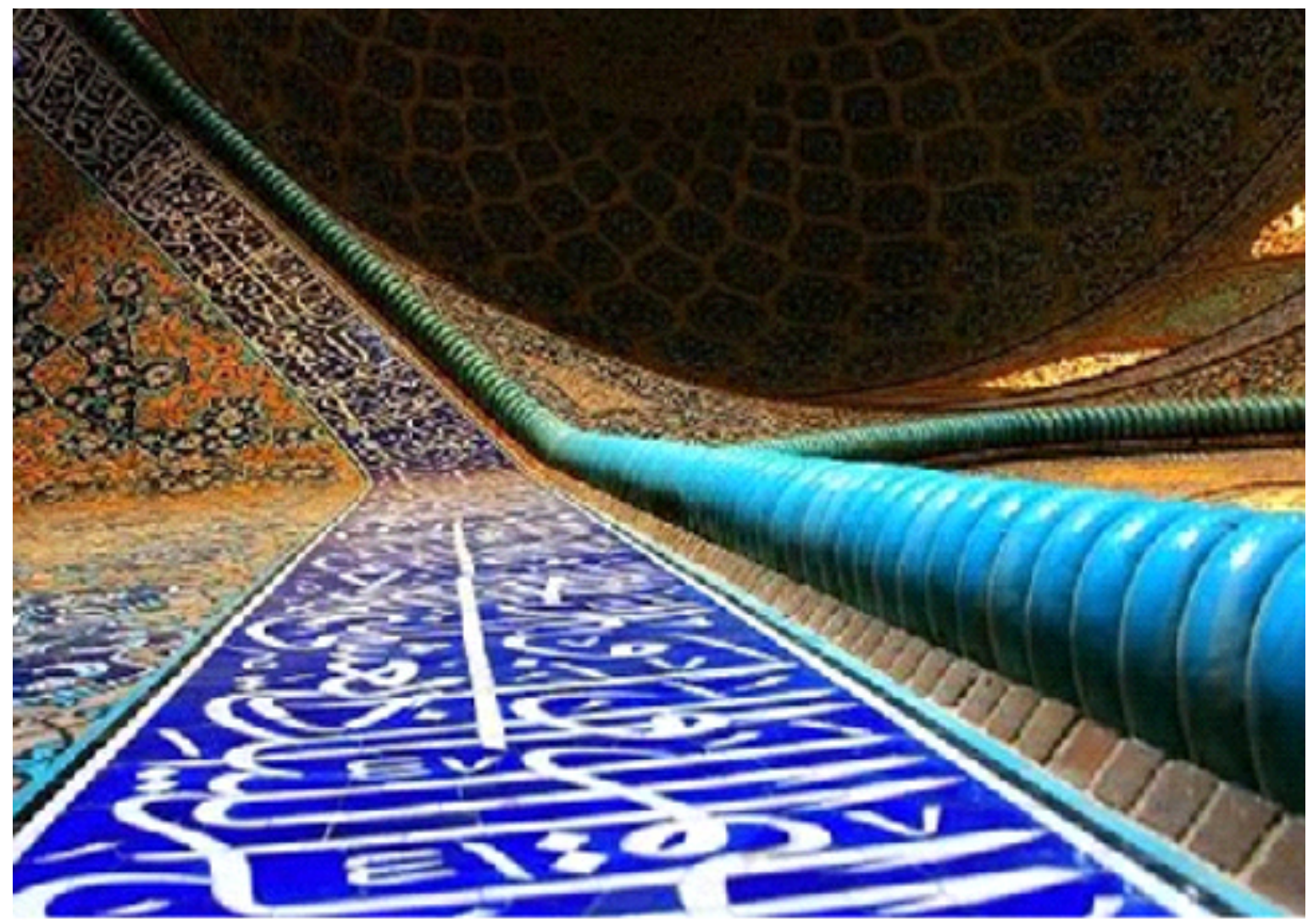

Picture- 2 source: the author

\section{SEVEN-COLOR TILE}

These types of tiles, contrary to their names, are not limited to seven colors and more colors are used in them. The background of these tiles must be glazed, because the entire process is done on the polished surface. Seven-color tiles were mostly used due to the significance of architecture, and the increasing construction of religious and non-religious buildings. As a result, the great utilization of tiles in Safavid period replaced mosaic tiles with seven color-tiles which were more time and cost effective. Designs and patterns on seven color tiles are drawn by brush, making it possible to combine different colors and draw delicate fine designs. Installing and implementing seven color-tiles is quite simple (Makkinejad, 2009) (Picture 3). 


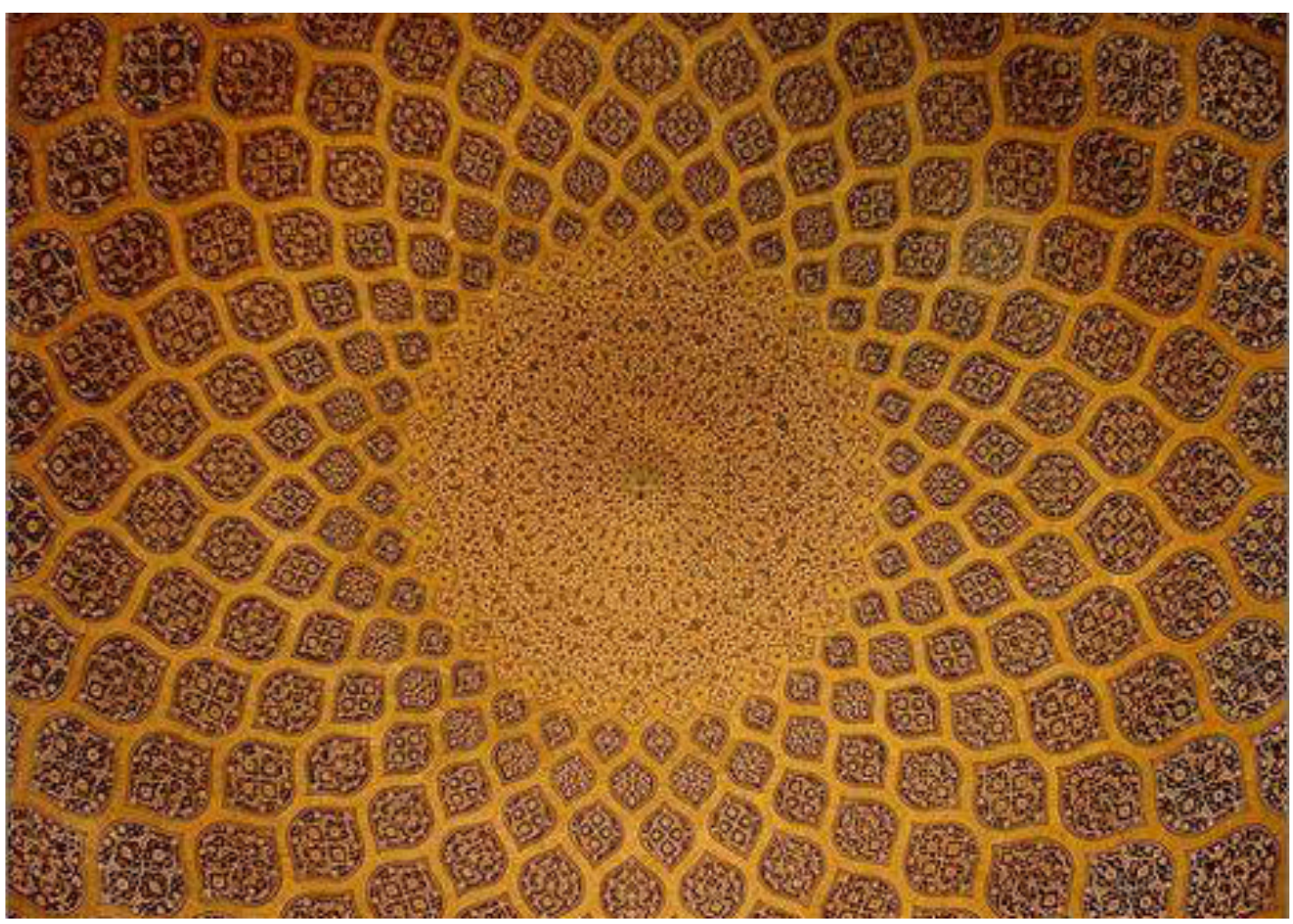

Picture-3 source: the author

\section{CONCLUSION}

Artists of the Safavid period are the heirs of the invaluable experiences and masterpieces created by previous artists. In fact the trend which started and continued from the early centuries of Islam to Timurid period in the field of architectural tiling decoration, remarkably continued by Safavid artists. In Safavid period, tile work reached its peak and most holy places were embellished by tiles. Sheikh Lotfollah mosque is one of the historical mosques of Safavid period located in NaghsheJahan Square of Isfahan. Elegant tile work has been performed in this mosque and images of flowers, plants and Quranic verses have been drawn on tiles. Orange color has been mostly used in this masterpiece which invokes vitality and charm in the beholder. This mosque is the result of the artistic excellence of the architect, painter and tile worker who have wholeheartedly applied their artistic talents for their faith in God and love of religion, so as to leave such a precious treasure for the next generations.

\section{REFERENCES}

Pope, Arthur (2009) Iranian Architecture, Translated by Gholamhossein Sadri Afshar, Akhtaran Publication, First Edition, Tehran

Shaterian, Reza (2011) Architectural Analysis of Iranian Mosques, Noorpardazan Publication, Tehran Siveri, Roger (1995) Iran in Safavid Period, Translated by KambizAzizi, Markaz Publication, Tehran Talbot, Rice (1995) Islamic Art in Safavid Period, Translated by NajafiBarzegar, Farhang and Honar Publication

Al-Refai, Anwar (1998) History and Art in Islamic lands, Translated by AbdolrahimGhanavat, JahadDaneshgahi Publication of Mashhad, Mashhad

Yavari, Hossein and Roqayyeh, Bavafa (2011) Isfahan, the Garden of the Sky, SimayeDanesh Publication, Tehran

Kiani, Mohammad Yousef (2004) History and Art of Iranian Architecture in Islamic Period, Tehran Art and Architecture of Mosques (2005), Secretariat of the Supreme Headquarters of the Coordination and Monitoring of Mosques Art and Cultural Centers, Tehran

MousaviBojnourdi, Kazem (2005) History, Culture, Art, the Great Islamic Encyclopedia Center, Tehran 
The Turkish Online Journal of Design, Art and Communication - TOJDAC July 2016 Special Edition

Albasini, Afif (2008) Islamic Art, Translated by Mohammad Pouraghasi, SourehMehr Publication, Second Edition, Tehran

Hatam, Gholamalai (1997) Mosque, Manifestation of Islamic Art, Journal of Art, No. 33

Honarfar, Lotfollah (1971) Isfahan, a Historical Treasure, Saghafi Publication, Isfahan

Makkinejad, Mahdi (2009) Architectural Decorations, Samt Publication of Tehran

Honarfar, Lotfollah (2004) Becoming Familiar with the Historical City of Isfahan, Golha Publication, Third edition, Isfahan 